\title{
Treatment of basal cell carcinomas and basaloid follicular hamartomas in basal cell nevus syndrome children and adolescents
}

Citation for published version (APA):

Verkouteren, B. J. A., \& Mosterd, K. (2022). Treatment of basal cell carcinomas and basaloid follicular hamartomas in basal cell nevus syndrome children and adolescents. Journal of Dermatological Treatment, 33(3), 1792-1793. https://doi.org/10.1080/09546634.2020.1840501

Document status and date:

Published: 03/04/2022

DOI:

10.1080/09546634.2020.1840501

Document Version:

Publisher's PDF, also known as Version of record

Document license:

Taverne

Please check the document version of this publication:

- A submitted manuscript is the version of the article upon submission and before peer-review. There can be important differences between the submitted version and the official published version of record.

People interested in the research are advised to contact the author for the final version of the publication, or visit the DOI to the publisher's website.

- The final author version and the galley proof are versions of the publication after peer review.

- The final published version features the final layout of the paper including the volume, issue and page numbers.

Link to publication

\footnotetext{
General rights rights.

- You may freely distribute the URL identifying the publication in the public portal. please follow below link for the End User Agreement:

www.umlib.nl/taverne-license

Take down policy

If you believe that this document breaches copyright please contact us at:

repository@maastrichtuniversity.nl

providing details and we will investigate your claim.
}

Copyright and moral rights for the publications made accessible in the public portal are retained by the authors and/or other copyright owners and it is a condition of accessing publications that users recognise and abide by the legal requirements associated with these

- Users may download and print one copy of any publication from the public portal for the purpose of private study or research.

- You may not further distribute the material or use it for any profit-making activity or commercial gain

If the publication is distributed under the terms of Article 25fa of the Dutch Copyright Act, indicated by the "Taverne" license above, 


\section{Treatment of basal cell carcinomas and basaloid follicular hamartomas in basal cell nevus syndrome children and adolescents}

\section{B. J. A. Verkouteren \& K. Mosterd}

To cite this article: B. J. A. Verkouteren \& K. Mosterd (2020): Treatment of basal cell carcinomas and basaloid follicular hamartomas in basal cell nevus syndrome children and adolescents, Journal of Dermatological Treatment, DOI: 10.1080/09546634.2020.1840501

To link to this article: https://doi.org/10.1080/09546634.2020.1840501

\section{曲 Published online: 01 Nov 2020.}

Submit your article to this journal $\widetilde{ }$

\section{Џ Article views: 39}

Q View related articles $\asymp$

View Crossmark data 


\section{Treatment of basal cell carcinomas and basaloid follicular hamartomas in basal cell nevus syndrome children and adolescents}

Dear Editor,

Patients with basal cell nevus syndrome (BCNS) can develop over hundreds of basal cell carcinomas (BCCs) in their lives, of which the first can already be seen in early childhood. In children and adolescents, typically tens of shiny, sometimes pigmented, papules can be present at once, histologically diagnosed as BCCs or basaloid follicular hamartomas (BFHs), recognized as part of the cutaneous tumor spectrum in BCNS (1). Surgery can be painful and traumatizing, and scars can be mutilating due to the high number of lesions in BCNS patients. Left untreated, the lesions can progress and treatment can be more challenging, resulting in larger scars. Imiquimod 5\% cream has proven to be a very effective noninvasive therapy for BCCs, with a cure rate of $\sim 80 \%, 5$ years after treatment (2). Prior curettage can shorten imiquimod treatment duration with comparable cure rates (3). Especially in BCNS, a large advantage is that multiple lesions can be treated at once. Here, we describe a case series of young BCNS patients with multiple small BCCs or BFH treated with curettage and imiquimod $5 \%$.

Between January 2017 and February 2020, 100 clinical BCCs or BFHs were treated with curettage followed by imiquimod cream application in 4 BCNS patients with a confirmed germline PTCH1 mutation. Curettage was performed under general anesthesia (for other reasons) in a 4-year old patient and an hour after application of lidocaine/prilocaine in the older patients $(14,19$ and 20 years old). Lesions were 1-5 millimeters and located on the trunk (77), neck (13), arms (6), legs (2), and face (2). In all patients, at least one lesion was histologically confirmed to be a BCC. A mean number of 14 lesions were curettaged per session (range 4-23) and patients applied imiquimod $5 \%$ cream 5 days/week during 6 weeks, using 1 sachet $(250 \mathrm{mg})$ per day. Treatment results were evaluated on follow-up visits each 4-6 months based on photographs taken before treatment (Figure 1). Median follow-up time of all BCCs was 11 months (range, 5-26 months), in which 6 of 100 BCCs recurred. One patient reported mild pain during both curettage (after lidocaine/prilocaine) and imiquimod treatment, but preferred it over excision. No other side effects were mentioned and none of the patients was lost to follow-up.

Imiquimod was previously described in the treatment of BCCs in 3 BCNS-children, with partial response following application 3 days/week for a total duration of at least 8 weeks (4). Based on the results of a recent RCT, we used the recommended schedule of 5 days per week for 6 weeks (3). Safety data on imiquimod treatment in children are sparse, but in several phase II trials there was low systemic exposure and side effects consisted mostly of application site reactions (5).

Based on our small case series, curettage followed by imiquimod $5 \%$ cream seems effective in the treatment of multiple small BCCs at once. The use of appropriate anesthesia is important to prevent traumatizing procedures in young BCNS patients who will need medical care for the rest of their lives.
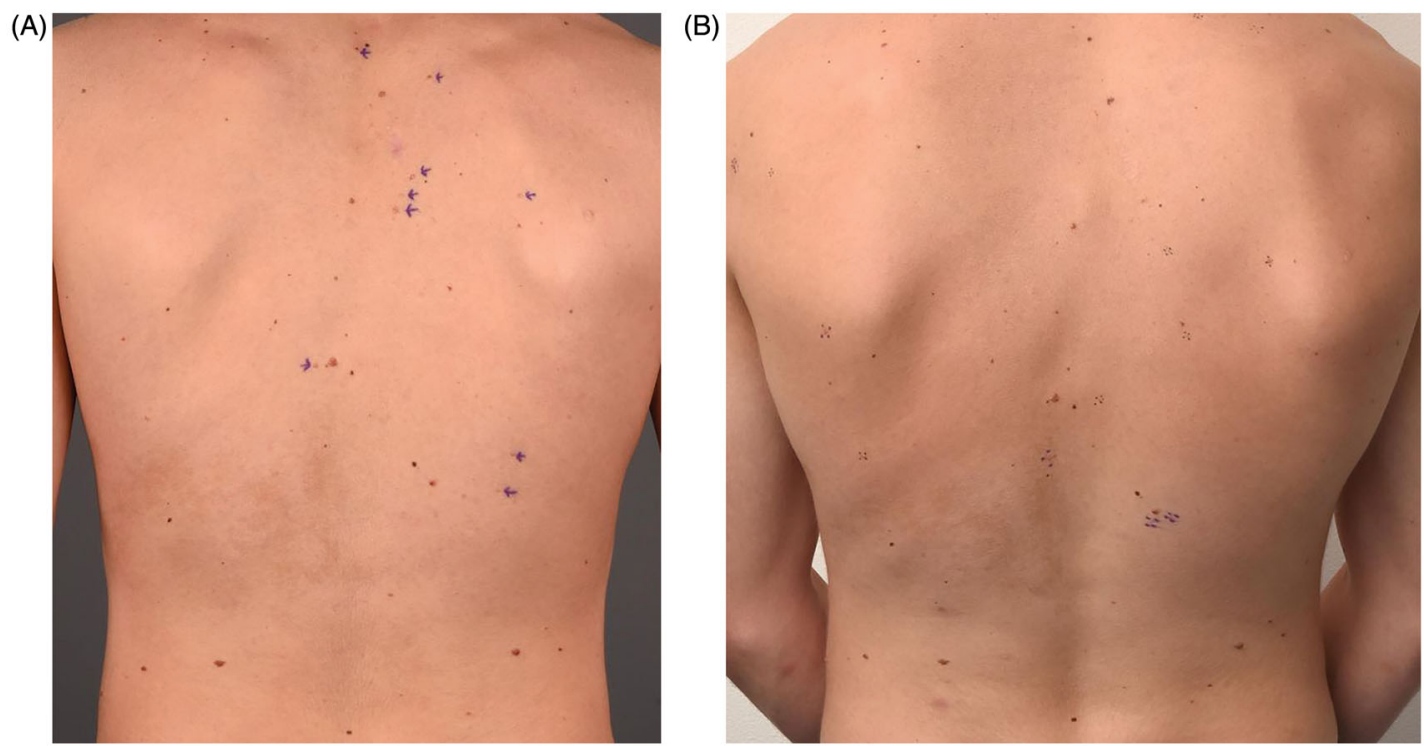

Figure 1. (A) Overview of the back of a patient before treatment; multiple lesions. (B) Overview of the back 26 months after treatment; no recurrences but multiple new lesions. 


\section{Disclosure statement}

No potential conflict of interest was reported by the author(s).

\section{Consent for publication}

The patient in this manuscript has given written informed consent to publication of the photographs.

\section{ORCID}

B. J. A. Verkouteren (iD http://orcid.org/0000-0002-2006-6467

K. Mosterd (D) http://orcid.org/0000-0002-9065-3050

\section{References}

1. Ponti G, Manfredini M, Pastorino L, et al. PTCH1 germline mutations and the basaloid follicular hamartoma values in the tumor spectrum of basal cell carcinoma syndrome (NBCCS). Anticancer Res. 2018;38(1):471-476.

2. Jansen MHE, Mosterd K, Arits A, et al. Five-year results of a randomized controlled trial comparing effectiveness of photodynamic therapy, topical imiquimod, and topical 5fluorouracil in patients with superficial basal cell carcinoma. J Invest Dermatol. 2018;138(3):527-533.
3. Sinx KAE, Nelemans PJ, Kelleners-Smeets NWJ, et al. Surgery versus combined treatment with curettage and imiquimod for nodular basal cell carcinoma: one-year results of a non-inferiority, randomized controlled trial. J Am Acad Dermatol. 2020;83(2):469-476.

4. Samela PC, Tosi V, Cervini AB, et al. Nevoid basal cell carcinoma syndrome: our experience in a pediatric hospital. Actas Dermosifiliogr. 2013;104(5):426-433.

5. Accesdata.fda.org [Internet]. Silver Spring (MD): U.S. Food and Drug Administration. [Last updated 2010 Oct, cited 2020 Aug 31]. Available from: https://www.accessdata.fda. gov/drugsatfda_docs/label/2010/020723s022lbl.pdf.

B. J. A. Verkouteren* and K. Mosterd Department of Dermatology, Maastricht University Medical Center, Maastricht, Netherlands

GROW School for Oncology and Developmental Biology, Maastricht University, Maastricht, The Netherlands (babette.verkouteren@mumc.nl

Received 11 September 2020; accepted 15 October 2020 (C) 2020 Taylor \& Francis Group, LLC 